\title{
UNGKAPAN RASA TERKEJUT DALAM RAGAM KANYOUKU
}

\author{
Yuliani Rahmah \\ Fakultas Ilmu Budaya Universitas Diponegoro \\ Email: yuliani.undip@gmail.com
}

\begin{abstract}
This paper describes about Kanyouku which used in Japanesse daily conversation. Kanyouku used to express what we feel about something more specific than the common sentences. There are many expressions of kanyouku, but this paper is focused on a kanyouku which used to show surprise expressions. Kanyouku that introduced in this description only 10 of Doushi Kanyouku types. Those kanyouku not only described the meanings but also given examples of simple sentences that are commonly encountered in daily conversation.
\end{abstract}

Keyword: Kanyouku, Doshi Kanyouku, surprise expression

\section{PENDAHULUAN}

Kanyouku adalah istilah yang digunakan untuk menunjukkan idiom dalam bahasa Jepang. Secara harfiah Kanyouku dapat diartikan sebagai gabungan dua kata atau lebih dalam bahasa Jepang yang mempunyai makna tertentu. Untuk mengerti makna yang terdapat dalam sebuah Kanyouku, para pembelajar bahasa dan sastra Jepang membutuhkan pemahaman yang cukup terutama tentang budaya Jepang karena Kanyouku akan sulit dipahami maknanya bila hanya melihat arti dari setiap kata yang membentuknya. Kesulitan tersebut disebabkan karena frase pendek yang digunakan dalam sebuah Kanyouku tidak bermakna leksikal. Meskipun terkadang sulit untuk dipahami secara leksikal, keberadaan Kanyouku sangatlah penting dalam komunikasi masyarakat Jepang. Kanyouku sering digunakan dalam ragam lisan seperti percakapan sehari-hari (Nichijou Kaiwa) maupun dalam bentuk tertulis seperti yang terdapat dalam komikkomik Jepang (manga)

Dibandingkan dengan kosakata baku bermakna leksikal, penggunaan Kanyouku dalam berkomunikasi dirasa lebih dapat mengungkapkan secara mendalam ekspresi perasaan yang sedang kita alami atau yang ingin kita sampaikan pada lawan bicara.Pada fungsinya sebagai media untuk mengungkapan ekspresi perasaan, Kanyouku banyak digunakan untuk mengungkapkan rasa cinta (aijoo), gembira (tanoshii), sedih (kanashii), terkejut (odoroku), marah (okoru), malu (hazukashii) dan sebagainya. Bahkan dalam sebuah buku berjudul Reikai Kanyouku Jiten (1992), dijelaskan bahwa setidaknya ada 55 jenis ekspresi perasaan yang dapat diungkapkan oleh ragam Kanyouku. Namun dari sekian banyak ekspresi perasaan tersebut, pada kesempatan ini penulis akan menjelaskan ekspresi perasaan terkejut (odoroku). Pada pemaparan berikutnya penulis akan menjelaskan bagaimana sebuah ekspresi keterkejutan akan mempunyai makna leksikal yang cukup berbeda bila diungkapkan dengan menggunakan ragam Kanyouku.

\section{PENGERTIAN KANYOUKU}

Pada bagian sebelumnya telah disebutkan mengenai makna dari kanyouku. Berikut ini akan dipaparkan secara terperinci mengenai Kanyouku yang sering digunakan dalam komunikasi masyarakat Jepang. Dalam Kokugo Jiten dijelaskan bahwa

$$
\begin{array}{r}
\text { 慣用句 : 二つ以上の箪語が結びつき、全体 } \\
\text { として特別の意味を表す言い方。 } \\
\text { イディオム。慣用語。(1991; 253) }
\end{array}
$$


Definisi tersebut dapat diartikan bahwa Kanyouku adalah cara pengucapan dari dua kata atau lebih yang digabungkan dan secara keseluruhan gabungan tersebut menunjukkan arti / makna yang khusus (berbeda)

Dalam bahasa Jepang Kanyouku dikenal juga dengan sebutan Kanyougo atau Kanyougoku Kata-kata yang digunakan pada ragam Kanyouku pun bermacam-macam bisa mengandung kata-kata dari strata sosial, dari bahasa kuno maupun dari kata-kata yang berasal dari dialek daerah. Dari sekian banyak contoh Kanyouku, berikut penulis berikan contoh sederhana dari penggunaan Kanyouku dalam kalimat.

1. a. 今日耳が痛いから、医者へ行かなけれ ばなりません。

Karena hari ini telinga saya sakit, saya harus pergi ke dokter

b.「スケベ」と言われて、耳が痛かった。

Panas kuping saya mendengar julukan "playboy"

\section{2. a. 彼は市場で油を売る。}

Dia menjual minyak di pasar

b. こんなところで油を売ってないで、早 く自分の席にすわて仕事をしなさい。

Jangan membuang-buang waktumu di tempat seperti ini, kembalilah ke tempatmu dan selesaikan pekerjaanmu

Kata-kata yang digunakan pada kalimat no 1 dan 2 di atas mengandung makna denotatif dan makna konotatif atau makna Kanyouku. Pada kalimat pertama kata yang mempunyai dua makna tersebut adalah kata mimi ga itai. Kalimat 1a bermakna denotatif yaitu "sakit telinga", sedangkan kalimat 1b makna kanyooku yang diungkapkan adalah "merasa jengah / merasa tidak tahan mendengar perkataan orang lain tentang diri kita". Sementara pada kalimat no 2 kata abura o uru pun bisa dimaknai dengan dua cara, makna denotaifnya yaitu "menjual minyak", sedangkan maknanya sebagai Kanyouku adalah "menghabiskan waktu untuk hal yang sia-sia".
Dari kedua contoh di atas dapat dilihat bahwa dalam memahami sebuah Kanyouku diperlukan pengetahuan dan pengalaman berbahasa Jepang yang memadai karena makna dari sebuah Kanyouku tidak dapat diterjemahkan hanya dengan melihat kamus standar saja.

\section{JENIS-JENIS KANYOUKU}

1. Dilihat dari arti dan makna yang dinyatakan oleh Kanyouku.

Bila dilihat dari maknanya maka terdapat 5 jenis Kanyouku yang termasuk dalam kategori ini, yaitu

a. 感覚・感情を表す慣用句, yaitu kanyouku yang menunjukkan arti yang berhubungan dengan perasaan)

b. 体 ・ 性格・態度を表表慣用句 yaitu Kanyouku yang menunjukkan arti yang berhubungan dengan badan, sifat dan sikap manusia

c. 好意・動作・行動を表す慣用句

yaitu Kanyouku yang menunjukkan arti yang berhubungan dengan perbuatan, pergerakan dan aktifitas

d. 状態・程度・価值を表す慣用句 yaitu Kanyouku yang menunjukkan arti yang berhubungan dengan situasi, tingkatan dan nilai dari suatu benda atau pekerjaan

e. 社会・文化・苼活を表す慣用句 yaitu Kanyouku yang menunjukkan arti yang berhubungan dengan masyarakat, budaya dan kehidupan manusia

2. Dilihat dari jenis kata pembentuknya

a. 動詞慣用句,

yaitu kanyouku yang terbentuk dari gabungan nomina dan verba

\section{b. 形容詞慣用句,}

yaitu kanyouku yang terbentuk dari gabungan nomina dan adjektiva

c. 名詞慣用句,

yaitu kanyouku yang terbentuk dari gabungan dua nomina 


\section{DEFINISI PERASAAN TERKEJUT DALAM BAHASA JEPANG}

Sebelum memaparkan mengenai Kanyouku yang digunakan untuk mengungkapkan ekspresi terkejut, terlebih dahulu penulis akan memaparkan beberapa definisi yang berhubungan objek penulisan kali ini, yaitu perasaan terkejut dan gambaran umum dari Kanyooku itu sendiri.

Dalam pengertian bahasa Jepang, kata "perasaan" atau "rasa" bisa diungkapkan dengan 3 (tiga) jenis kata yaitu Kanjoo, Kankaku dan Kanji. Dalam Kokugo Jiten (1991) ketiga kata tersebut dijelaskan sebagai berikut

感情 : (1) 喜怒哀楽・快不快などの心の状 態。気持ち。心持ち。

(2) 外からの刺激に反応して起こる 心の変化 $\quad(1991 ; 246)$

Definisi di atas dapat diartikan sebagai berikut : Kanjoo adalah

(1) perasaan gembira,marah,sedih,suka. Keadaan hati yang merasakan senang,tidak senang. Perasaan.Suasana hati

(2) perubahan hati yang terjadi karena respon dari sebuah rangsangan yang datang dari luar.

\section{感覚：目・鼻・耳・舌・ひふなどの感覚 器官（五官）が外部の刺激感じと るはたらき。また、その刺激によ って、生じる意識。}

Definisi di atas dapat diartikan bahwa Kankaku adalah sesuatu yang dirasakan melalui mata,hidung, telinga, lidah, kulit dan sebagainya (panca indera). Selain itu juga merupakan kesadaran yang disebabkan oleh sebuah rangsangan

感じ：(1) 何かに接したときに心に浮かん だ思い。心にうける気持ち。

(2)五官の刺激による感覚。

$(1991 ; 244)$
Definisi di atas dapat diartikan sebagai berikut: Kanji adalah

(1) Perasaan yang timbul setelah menerima rangsangan.

Rasa yang timbul karena rangsangan pada panca indera.

Dari ketiga definisi di atas penulis menyimpulkan bahwa rasa terkejut yang akan penulis paparkan termasuk dalam kategori Kanjoo, karena mengungkapkan suasana atau goncangan yang dialami oleh hati seseorang.

Dilihat dari ekpresi perasaan yang diungkapkannya, kata "terkejut" dalam bahasa Indonesia mempunyai makna yang berbeda-beda. Untuk mengungkapkan rasa terkejut, kita bisa menggunakan kata-kata seperti terperanjat, terhenyak/ tersentak, dan tercengang/ terpana/terpukau. Seperti halnya bahasa Indonesia, dalam bahasa Jepang pun kata yang bisa digunakan untuk menunjukkan keterkejutan tidak hanya kata odoroku atau bikkuri suru saja seperti yang sering digunakan oleh para pembelajar bahasa Jepang dalam bahasa percakapan sehari-hari. Dalam buku berjudul Nita Kotoba Tsukaiwake Jiten(1991; 88) disebutkan bahwa untuk menunjukkan rasa terkejut dapat digunakan kata odoroku, bikkuri suru, tamageru,kyougaku suru, dan kyoutan suru. Secara singkat kata-kata tersebut dapat dijelaskan sebagai berikut ;

1. Odoroku adalah kata yang digunakan untuk menunjukkan keadaan terkejut karena mengalami sesuatu yang tidak diduga/ diperkirakan sebelumnya datang dengan tibatiba, dan untuk sesaat hati mendapat guncangan.

Contoh：大きな物の音に驚く。

(terkejut karena mendengar bunyi yang sangat keras)

2. Bikkuri suru adalah kata yang digunakan untuk menunjukkan keadaan terkejut akan sesuatu kejadian/hal yang tidak pernah terlintas sedikitpun dalam pikirannya.

Contoh ; 值を聞いてびっくりする。

(terkejut begitu mendengar harga barang tersebut) 
3. Tamageru adalah kata yang digunakan untuk menunjukkan keadaan seperti kehilangan kesadaran karena rasa takut/ dikejutkan oleh sesuatu

Contoh ; 暗がりから人が出ていたので、 たまげた。

(terkejut karena tiba-tiba muncul seseorang dari kegelapan)

4. Kyougaku suru adalah kata yang dibaca dengan lafal China dan mempunyai arti yang hampir sama dengan Odoroku, hanya saja pada ungkapan ini seringkali terkandung makna sedih, khawatir dan sebagainya.

Contoh ; 訃報に接し、篤愕する

kematian )

(terkejut mendengar berita

5. Kyoutan suru adalah kata yang menunjukan keadaan terkejut yang disertai perasaan haru karena mendapatkan hasil yang memuaskan atau mengalami peristiwa yang mengagumkan

Contoh ; 役者の妙技に驚嘆する。

(terkejut dengan prestasi yang ditampilkan oleh aktor tersebut)

Dari definisi di atas maka penulis menyimpulkan bahwa istilah odoroku dan bikkuri suru merupakan sebuah ungkapan yang digunakan untuk menunjukkan perasaan terkejut secara umum, sedangkan untuk keterkejutan yang disertai dengan perasaan yang ungkapannya lebih spesifik maka istilah yang dapat digunakan adalah tamageru, kyougaku suru dan kyoutan suru.

\section{UNGKAPAN TERKEJUT DALAM RAGAM KANYOUKU}

Dalam percakapan masyarakat Jepang banyak sekali Kanyouku yang mereka gunakan untuk menunjukkan rasa terkejut.Namun pada uraian kali ini penulis akan menjelaskan beberapa saja diantaranya sebagai pengenalan dan gambaran umum bagi para pembelajar bahasa Jepang yang mempunyai ketertarikan pada Kanyouku. Berikut jenis Doushi kanyouku yang mempunyai arti terkejut

\section{1.姜を蛽す}

意味：非常に驚いて慌てふたむく (Inoue,1995;22)

例：(1)子どもが突然車の前に飛び出して 来たのには肝を潰し

(Inoue,1995;22)

(2)目の前でオートバイ事故が起きた ときは肝をつぶすかと思った。

(Sakata、1994;88)

Kimo dalam bahasa Jepang bisa berarti hati ataupun nyali, sedangkan tsubusu mempunyai arti menghancurkan. Sehingga secara harfiah arti kata di atas adalah menghancurkan hati atau menghancurkan nyali.

Tetapi bila dilihat dari definisi dan contoh kalimatnya, maka dapat dilihat tingkat keterkejutan yang dialami oleh si pembicara, sehingga kimo o tsubusu adalah kanyouku yang dapat digunakan untuk mengungkapkan perasaan seseorang ketika mengalami keterkejutan luar biasa seolah-olah menghancurkan nyalinya dan menimbulkan kepanikan pada diri si pembicara. Hal tersebut dapat dilihat dari contoh kalimat yang menggambarkan bagaimana terkejutnya si pembicara ketika tepat di depan mobil yang sedang dikendarainya meloncat seorang anak (contoh (1) atau ketika tepat di depan matanya terjadi kecelakaan sepeda motor (contoh (2)).

Bila diungkapkan dengan bahasa Jepang maka keterkejutan seperti ini termasuk pada definisi Odoroku.

2.腰を抜かす・腰が抜ける (Koshi o nukasu / Koshi o nukeru)

意味：

・ 非常に驚いて体を動かすこともで きなくなる。（Inoue,1995;22）

・ あまりの驚きや恐怖のために腰の 力が抜け、立ち上げられなくなる 意で、強いショックを受け 茫然自失 寸 る 様子 (Sakata,1994;130) 
例：(3) 山に歩いていたら、突然クマが出 てきたので、腰を抜かしてしまった。

(4)夜、暗闇から突然ネコが私に飛 びかかってきて腰を抜かしてしまった。

(5) 夫が癌だと聞かされ、腰が抜け たように座り込んでしまった。

Koshi dalam bahasa Jepang berarti pinggang, sedangkan nukeru mempunyai arti lepas, sehingga secara harfiah arti kata di atas adalah pinggangnya lepas.

Tetapi bila dilihat dari definisi dan contoh kalimatnya, maka keterkejutan yang dialami oleh si pembicara membuatnya untuk beberapa saat diam tidak bergerak terpaku karena sesuatu, sehingga koshi o nukasu / koshi ga nukeru adalah kanyouku yang dapat digunakan untuk mengungkapkan perasaan seseorang ketika mengalami keterkejutan karena sesuatu yang dilihat atau didengarnya di luar dugaan dan menimbulkan rasa takut sehingga membuat tubuhnya menjadi kaku tidak bisa bergerak karena seolah-olah pinggangnya terlepas. Dalam bahasa Indonesia kanyouku ini mempunyai arti yang sama dengan jantung copot. Hal tersebut dapat dilihat dari contoh kalimat yang menggambarkan bagaimana terkejutnya si pembicara ketika di jalan setapak sebuah pegunungan yang sedang dilewatinya tiba-tiba melompat seekor beruang (contoh (3)) atau ketika pada malam hari dari tempat gelap melompat seekor kucing (contoh (4)). Sama halnya dengan keterkejutan yang digambarkan pada contoh (5) ketika si pembicara mendengar bahwa suaminya menderita penyakit kanker. Ketiga contoh di atas menggambarkan bahwa pembicara merasa terkejut sekaligus takut dan khawatir oleh hal yang dialaminya.

Bila diungkapkan dengan bahasa Jepang maka keterkejutan seperti ini termasuk pada definisi Tamageru.

3. 筈を巻く

意味 :

- 人の行いにひどく驚き感心する。 (Murayama,1990;30)
・言葉も出ないほど驚いたり感心す ることだ。（Tanaka,1994;30）

例：(6)大学入試の問題を荃部解いた中 学生がいると知って舌を巻く。

７）彼女は５か国語を自由に話せる。 あの語学力には皆を巻く。 (Tanaka、1994;36\&37)

Shita dalam bahasa Jepang berarti lidah, sedangkan maku mempunyai arti menggulung, sehingga secara harfiah arti kata di atas adalah menggulung lidah.

Tetapi bila dilihat dari definisi dan contoh kalimatnya, maka keterkejutan yang dialami oleh si pembicara merupakan keterkejutan yang disebabkan oleh rasa kagum, sehingga shita o maku adalah kanyouku yang dapat digunakan untuk mengungkapkan perasaan seseorang ketika mengalami keterkejutan karena sesuatu yang membuatnya terkesan dan kagum. Kesan yang diperoleh si pembicara tidak bisa diungkapkan dengan kata-kata karena seolaholah lidahnya menggulung karena rasa kagum. Hal tersebut dapat dilihat dari contoh kalimat yang menggambarkan bagaimana rasa terkejut sekaligus kekaguman si pembicara mendengar ada siswa SMP yang mampu menyelesaikan soal-soal ujian masuk perguruan tinggi (contoh (6)) atau ketika melihat seseorang yang mampu berbicara dalam 5 bahasa dengan fasih (contoh (7).

Bila diungkapkan dengan bahasa Jepang maka keterkejutan seperti ini termasuk pada definisi Kyoutan suru.

4.甙自を驚が

意味 : 世間の人々に衝撃を与え、驚かせ る。(Inoue,1995;22)

例 : 8) 多国籍軍のイラクへの空爆開始の ニュースは全世界の人々の耳目を 驚かせた。

(9) 前人未到の大記録を達成して、世 の耳目を驚かせた。

Jimoku dalam bahasa Jepang berarti mata telinga, sedangkan ugokasu mempunyai arti 
mengejutkan, sehingga secara harfiah arti kata di atas adalah mengejutkan mata dan telinga.

Tetapi bila dilihat dari definisi dan contoh kalimatnya, maka keterkejutan yang dikatakan oleh si pembicara merupakan keterkejutan yang dirasakan oleh orang banyak (secara umum) baik atas sesuatu yang bersifat negatif maupun positif, sehingga Jimoku o odorokasu adalah kanyouku yang dapat digunakan untuk mengungkapkan peristiwa yang menimbulkan perasaan terkejut pada semua orang baik karena khawatir dan takut maupun karena terkesan dan kagum. Keterkejutan yang ditimbulkan berlaku secara menyeluruh sehingga diibaratkan dengan bagian anggota tubuh, bukan hanya telinga yang dibuat terkesan/ khawatir dengan apa yang didengarnya tetapi matapun dibuat kagum/ takut oleh sesuatu yang dilihatnya. Hal tersebut dapat dilihat dari contoh kalimat yang menggambarkan bagaimana rasa terkejut masyarakat dunia dengan adanya berita penyerangan negara sekutu terhadap Irak (contoh (8) ), atau kekaguman masyarakat terhadap orang yang telah berhasil memecahkan rekor dunia (contoh (9)).

Bila diungkapkan dengan bahasa Jepang maka keterkejutan seperti ini bisa termasuk pada definisi Kyoutan suru maupun Kyougaku suru.

\section{5.桨桨耳に水}

意味：

- 思いもよらない突然の出来事に、 ひどく驚くこと。（Inoue,1995； 23)

・突然思いがけないことが起きて驚 くことの例えだ。（Murayama、 $1990 ; 40)$

例：10交通事故で同僚が死んだという知 らせは寝耳に水であった。（Inoue,1995；23）

Nemimi dalam kanyouku di atas merupakan gabungan dua kata yaitu Neru (tidur) dan mimi (telinga). Dalam bahasa Jepang gabungan kedua kata tersebut bisa berarti telinga seseorang yang sedang tertidur, sedangkan mizu artinya air, sehingga secara harfiah arti kata di atas adalah meneteskan air ke dalam telinga orang yang sedang tertidur. Tetapi bila dilihat dari definisi dan contoh kalimatnya, maka makna keterkejutan dalam kanyouku di atas merupakan keterkejutan yang dirasakan oleh si pembicara karena sebuah berita yang baru saja didengarnya. Nemimi ni mizu adalah kanyouku yang dapat digunakan untuk mengungkapkan perasaan terkejut karena mendengar berita atau peristiwa yang terjadi di luar dugaan atau diluar perkiraan si pembicara. Rasa terkejut yang luar biasa ini diibaratkan seperti terkejutnya orang yang terbangun dari tidur lelapnya karena tetesan air yang masuk ke dalam telinganya.Hal tersebut dapat dilihat dari contoh kalimat yang menggambarkan bagaimana terkejutnya si pembicara ketika mendengar berita bahwa teman kerjanya meninggal karena kecelakaan (contoh (10). Bila diungkapkan dengan bahasa Jepang maka keterkejutan seperti ini bisa termasuk pada definisi Kyougaku suru.

6.焣に疑ゔ

意味：

・予想もしないことを突然に聞かさ れて、どうしてもそれが信じられ ない。 (Inoue,1995; 23)

・聞いたことがすぐには信じられな くて聞き違いではないかと思う。

(Tanaka ,1994;16)

例：(11彼女があんなひどいことを言うな んて、自分の耳に疑う。

(Tanaka,1994;30)

(12)コンテストで優勝する自信がな かったら、自分の名前を呼ばれ たときにはうそではないかと耳 疑う。（Tanaka，1994；16）

Mimi dalam bahasa Jepang berarti telinga, sedangkan utagau mempunyai arti meragukan atau mempertanyakan, sehingga secara harfiah arti kata di atas adalah meragukan atau mempertanyakan telinga. Tetapi bila dilihat dari definisi dan contoh kalimatnya, maka keterkejutan yang dikatakan oleh si pembicara merupakan rasa terkejut yang diikuti dengan rasa tidak percaya akan atas apa yang baru saja didengarnya, sehingga Mimi ni utagau adalah kanyouku yang dapat digunakan untuk mengungkapkan ketidak percayaan pembicara akan berita mengejutkan yang tidak pernah terfikirkan sebelumnya. Keterkejutan yang ditimbulkan membuat pembicara tidak yakin dan meragukan apa yang didengarnya, seolah- 
olah dia bertanya pada telinganya sendiri tentang benar tidaknya berita tersebut. Ungkapan ini bisa digunakan untuk sebuah keterkejutan karena berita yang bagus maupun berita buruk.Hal tersebut dapat dilihat dari contoh kalimat yang menggambarkan bagaimana rasa terkejut si pembicara yang tidak percaya akan kata-kata yang diucapkan oleh wanita yang dikenalnya (contoh (11)). Pada contoh (12) si pembicara terkejut dan tidak percaya ketika mendengar namanya dipanggil sebagai juara dalam sebuah kontes. Bila diungkapkan dengan bahasa Jepang maka keterkejutan seperti ini bisa termasuk pada definisi bikkuri suru maupun kyoutan suru .

\section{7.胸が潰れる}

意味 :

・驚いて胸がどきどきする。 (Inoue, $1995 ; 23$ )

- 突然の出来事に驚いてはっとする。 (Murayama、1990；36)

例：13突然大声なんか出してあんまりび っくりさせるから胸が潰れると思っ た。(Inoue,1995;23)

Mune dalam bahasa Jepang bisa berarti dada, sedangkan tsubureru mempunyai arti hancur. Sehingga secara harfiah arti kata di atas adalah dadanya hancur. Tetapi bila dilihat dari definisi dan contoh kalimatnya, maka dapat dilihat si pembicara mengalami keterkejutan yang luar biasa, sehingga mune ga tsubureru adalah kanyouku yang dapat digunakan untuk mengungkapkan perasaan seseorang yang sangat terkejut dengan kejadian yang datang secara tiba-tiba sampai jantungnya berdetak dengan keras dan seolah-olah dadanya akan hancur karena detakan tersebut. Hal tersebut dapat dilihat dari contoh kalimat yang menggambarkan bagaimana terkejutnya si pembicara ketika tiba-tiba mendengar suara yang sangat keras.(contoh (13) ) . Bila diungkapkan dengan bahasa Jepang maka keterkejutan seperti ini termasuk pada definisi Odoroku atau bikkuri suru.

\section{8.胸を突く}

意味：
・強い衝撃を心に受ける。驚きは つとする。（Inoue,1995；23）

・急に何かが起こり、ドキッとする。 心配事などで、胸がいっぱいにな る。（Murayama、1990；65)

例：(14) 数日前久しぶりに会って一杯やっ た友人の突然の訃報に胸を突かれ た。（Inoue, $1995 ; 24$ )

(15) 不意に悲しみが胸を突き、涙がこみ上げ てきた。

(Murayama、1990 ; 305)

Seperti yang dijelaskan pada point 17 , mune dalam bahasa Jepang berarti dada, sedangkan tsuku artinya menusuk, sehingga secara harfiah arti kata di atas adalah menusuk dada. Tetapi bila dilihat dari definisi dan contoh kalimatnya, maka keterkejutan yang dialami oleh si pembicara disebabkan oleh sesuatu yang membuatnya shock, sehingga mune o tsuku adalah kanyouku yang dapat digunakan untuk mengungkapkan perasaan terkejut karena hatinya mengalami guncangan akibat suatu peristiwa. Keterkejutan yang dialami si pembicara menimbulkan rasa sedih dan khawatir. Hal tersebut dapat dilihat dari contoh kalimat yang menggambarkan bagaimana terkejut dan terguncangnya si pembicara mendengar berita kematian seorang teman lama yang beberapa hari sebelumnya dia temui.(contoh (14)), atau kesedihan yang dirasakan pembicara sehingga dia tidak dapat menahan airmatanya. (contoh (15) Bila diungkapkan dengan bahasa Jepang maka keterkejutan seperti ini bisa termasuk pada definisi Kyougaku suru.

\section{9.目が飛び出る}

意味：值段が非常に高くてびっくりす る様子。（Inoue,1995；24）

例 : (16) 今年は雨が少なかったので、野 菜の值段は目が飛び出るほど高い。

(17)「えつ。この小さい洋服が 5 万 円?!」子どもの洋服は目が出 るほど高い。（Tanaka ,1994； 20\&21)

Me adalah mata, sedangkan tobideru mempunyai arti melompat, sehingga secara 
harfiah arti kata di atas adalah matanya melompat. Tetapi bila dilihat dari definisi dan contoh kalimatnya, maka keterkejutan yang dikatakan oleh si pembicara merupakan keterkejutan yang disebabkan oleh sesuatu yang diluar perkiraan terutama berhubungan dengan harga, sehingga me ga tobideru adalah kanyouku yang dapat digunakan untuk mengungkapkan perasaan terkejut ketika melihat harga suatu barang yang dianggap tidak lazim. Hal tersebut dapat dilihat dari contoh kalimat yang menggambarkan bagaimana rasa terkejut si pembicara melihat harga sayuran dan baju anakanak yang akan dilihatnya.(contoh (16)), atau kekaguman masyarakat terhadap orang yang telah berhasil memecahkan rekor dunia (contoh (17)

Bila diungkapkan dengan bahasa Jepang maka keterkejutan seperti ini bisa termasuk pada definisi bikkuri suru.

10.目を疑う

意味：

・思いよらないものを見た驚きで、 自分の見たことが信じられない。 (Inoue,1995; 24)

・実際に見たことが信じられなくて、 とても驚く。（Tanaka，1994；16）

例：(18) 大学受験したが、たぶんだめだ ろうと思っていたので、 ごうかくつうち 合格通知を見たときは目を疑っ た。

19道で 1万円札の束を見つけた時は 自分の目を疑った。

(Tanaka,1994;22\&23)

Makna kanyouku ini hampir sama dengan makna kanyouku Mimi ni Utagau, yang meragukan atau mempertanyakan anggota badan, hanya saja disini yang diragukan adalah mata.
Keterkejutan yang dirasakan oleh si pembicara merupakan rasa terkejut yang diikuti dengan rasa tidak percaya akan atas apa yang baru saja dilihatnya, sehingga Me Utagau pun merupakan kanyouku yang dapat digunakan untuk mengungkapkan ketidak percayaan pembicara akan berita mengejutkan yang tidak pernah terfikirkan sebelumnya. Keterkejutan yang ditimbulkan membuat pembicara tidak yakin dan meragukan apa yang dilihatnya, seolah-olah dia bertanya pada matanya sendiri.Hal tersebut dapat dilihat dari contoh kalimat yang menggambarkan bagaimana rasa terkejut si pembicara yang tidak percaya akan pengumuman kelulusan yang dilihatnya. (contoh (18). Pada contoh (19) si pembicara terkejut dan tidak percaya ketika menemukan tumpukan uang di jalan. Bila diungkapkan dengan bahasa Jepang maka keterkejutan seperti inipun termasuk pada definisi bikkuri suru maupun kyoutan suru .

\section{KESIMPULAN}

Pengungkapan sebuah ekspresi lebih spesifik ketika digunakan dengan ragam Kanyouku dibandingkan pengungkapan dengan kalimat biasa. Ekspresi rasa terkejut bila diungkapkan dalam bentuk kalimat bahasa Jepang biasa maka biasanya digunakan kata odoroku ataupun bikkuri suru, namun ketika hal tersebut diungkapkan dalam ragam Kanyouku maka kita akan dapat menunjukkan makna yang berbeda untuk rasa terkejut yang kita maksud.

Dari 10 kanyouku yang dijelaskan di atas, maka pengungkapan ekspresi terkejut dapat diklasifikasikan menjadi terperanjat (odoroku/bikkuri suru) yang terdapat dalam kanyouku 肝を潰す, 胸が潰れる dan 目が飛 び出る, tercengang (Kyoutan suru)yang terdapat dalam kanyouku 舌を巻く, 耳目を驚 か寸，耳に疑う，dan 目を疑う dan terhenyak yang terdapat dalam kanyouku 腰を抜か寸,耳 目を驚か寸 dan 胸を突く 


\section{DAFTAR PUSTAKA}

Inoue,Muneo. Reikai Kanyouku Jiten.1995. Tokyo: Shougakkan

Matsumura,Akira.Kokugo Jiten.1991. Tokyo:Obunsha.

Murayama, Makoto. Kotowaza Kanyouku Omoshiroi Jiten.Tokyo:Shougakkan

Sakata, Yukiko. Sanseido Jitsuyou Kanyouku Jiten.1994. Tokyo:Sanseido Henshuujo

Tanaka, Masae. Oboete Benrina Kanyouku.1994.Tokyo:Senmon Kyouiku Publishing 